\title{
Effects of social and family factors on viral respiratory infection and illness in the first year of life
}

\author{
GREGORY GARDNER, ${ }^{1}$ ARTHUR L FRANK, ${ }^{12}$ AND LARRY H TABER 12 \\ From the Influenza Research Center, ${ }^{1}$ Department of Microbiology and Immunology, and Myers-Black \\ Infectious Diseases Section, ${ }^{2}$ Department of Pediatrics, Baylor College of Medicine, Houston, Texas, USA
}

SUMMARY A total of 131 infants were monitored from birth through the first year of life for respiratory viral infection and illness and evaluated for the relationship that these had to certain social and familial factors. The results showed no general patterns of association between viral infection and the study factors, but there were several significant individual associations. Excess influenza virus infection was found for black infants, infants with at least one sibling, and especially those with school age siblings. Rhinovirus infection rates were highest among girls attending daycare. In addition, significantly higher rates of lower respiratory disease (LRD) were seen in daycare infants and low socioeconomic infants and a definite trend to increasing amounts of LRD was seen with increasing family size. Protection from LRD seen in girls was apparently lost in daycare. No convincing differences for viral infection or respiratory illness were seen with parental smoking as an isolated factor.

Viral respiratory illness is a major cause of morbidity and mortality in infancy. Children under 1 year of age have the highest incidence of acute respiratory illness ${ }^{1-3}$ and most are apparently caused by viruses. ${ }^{1}$

Social and family factors influence the incidence of illness during infancy ${ }^{4-6}$ but documented infection rates have been less frequently studied. For this reason we examined both infection and illness during the first year of life of 131 infants followed up in the Houston Family Study between 1975 and 1980.

\section{Materials and methods}

\section{RECRUITMENT AND MONITORING}

General methods used in the Houston Family Study have been reported previously..$^{7 \rightarrow} A$ total of 131 infants were observed for the first year of life from 1975 to 1980 . In 1975-6 recruitment of pregnant women took place at Jefferson Davis, a county hospital; thereafter all recruiting was from the community at large at an average of two or three families a month. The infants had blood obtained at birth (cord blood) and at 4,8 , and 12 months of age. Home visits were made every week during the respiratory virus season (biweekly at other times) for history and physical examination and to obtain nasal wash specimens for virus culture from infants. Additional home or clinic visits were made as needed for sampling of all illnesses. Diagnoses were made by a physician, nurse, or physician's assistant.

Records of all clinical contacts were available for review of illnesses. Upper respiratory illnesses (URI) were categorised as afebrile, febrile, or otitis media. For lower respiratory disease (LRD), the categories were laryngotracheobronchitis (LTB), bronchiolitis, or pneumonia. On review, illnesses lasting more than two weeks could usually be reinterpreted as two or more illnesses. When difficulty arose as to the nature or duration of an illness, the impressions of people seeing the child during the illness were used.

\section{LABORATORY METHODS}

Tissue cultures used for virus isolation were rhesus monkey kidney, MDCK, LLC-MK2, HEP-2, and WI-38. ${ }^{1011}$ Some specimens were inoculated into fertilised hen's eggs. ${ }^{12}$ Serological tests included haemagglutination inhibition for influenza $A$ and $B^{12}$ and microneutralisation for respiratory syncytial virus (RSV), parainfluenza virus types 3 (para 3 ), ${ }^{13}$ and influenza $A$ and $B .^{14}$ Fourfold rise in antibody titre (or failure of passively acquired antibody to fall) was considered evidence of infection.

SOCIAL AND FAMILY FACTORS

Personal and family data were obtained on enrolment and then recorded for each subsequent 
year. Six factors were studied: sex, race, parental smoking, socioeconomic class, number of siblings, and attendance at daycare. Race was white or nonwhite with the latter including blacks and MexicanAmericans. An infant was considered exposed to parental smoking if either mother or father or a livein relative smoked five or more cigarettes a day. An infant was considered a daycare attender if attendance at a daycare facility or mother's day out (sponsored by local churches) was consistent for at least five months. Finally, socioeconomic class was "low" if the family was eligible for the county hospital or made less than $\$ 12000$ a year, "medium" if the family had private medical insurance or made more than $\$ 12000$ a year, and "high" if the family had private medical insurance, made more than $\$ 12000$ a year, and one or both parents had attended at least three years of college.

ANALYSIS

Viral infection and respiratory illness rates were analysed for each family factor category. The mean number of infections or illnesses was calculated from the total number of episodes and reported as the rate per 100 child years. Chi-square analysis was done on the distribution of the data.

\section{Results}

From 1976 to 1980,92 infants (including three sets of twins) from 75 families were followed up. There were 59 whites, 24 blacks, and nine MexicanAmericans. Forty two per cent of the black and Mexican-American families were in the low socioeconomic group compared with $15 \%$ of the white families. The 39 infants studied from spring 1975 to spring 1976 will be included in selected analyses only because of socioeconomic imbalance (38 of 39 in low socioeconomic class) and some limitation in detailed clinical information on minor or non-influenza A illnesses, or both, during this first study year. This group was composed of 13 white, 21 black, and five Mexican-American infants.

\section{VIRUS INFECTION}

The figure shows the number of infections documented for the four viruses where serology was used in addition to virus isolation. Respiratory syncytial virus (RSV) had the largest proportion of infections identified by serological methods alone (63\%). Of 40 influenza $A$ and $B$ infections (35 type $A$ and five type B), $40 \%$ were identified by serology alone. In addition, $42 \%$ of the parainfluenza type 3 (para 3) infections were identified by serology alone. The remainder of the infections shown in tables 1 and 2 for these four agents were identified by isolation alone or isolation plus fourfold serological rise.
Table 1 shows the virus infection according to the selected social and family factors. In general, these factors were not significantly related to rates of proved viral infection. There were, however, some interesting exceptions.

Adenovirus infection rates were significantly associated with the number of siblings and daycare attendance. Infants with one sibling had the highest rate of infection while those with no siblings had the lowest. Infants with one sibling more often attended daycare $(41 \%)$ when compared with those with none or two or more sibling infants $(19 \%$ and $15 \%$ respectively); this may have influenced the chi square results. Numbers became too small when further analyses of daycare by number of siblings was done for adenovirus infection so the influence of the two factors could not be separated.

Both sex and daycare attendance were significantly associated with rhinovirus infection. Girls attending daycare had a much higher rate of rhinovirus infection (169) than did boy daycare attenders (50) or all infants not in daycare (48). In addition, 54\% of girl daycare attenders had multiple infections compared with $20 \%$ of the boys: $77 \%$ of girls in daycare had had at least one infection compared with $53 \%$ for all infants combined.

Seventy four per cent of low socioeconomic class infants had had at least one para 3 infection compared with $47 \%$ for medium socioeconomic class and 54\% for high, and this is reflected in the trend (not significant) in overall infection rates. None of the viruses considered was significantly associated with parental smoking for 1976-80. A significant relationship was found only for RSV and smoking mothers at home $(p=0 \cdot 020)$ when $1975-6$ data were included.

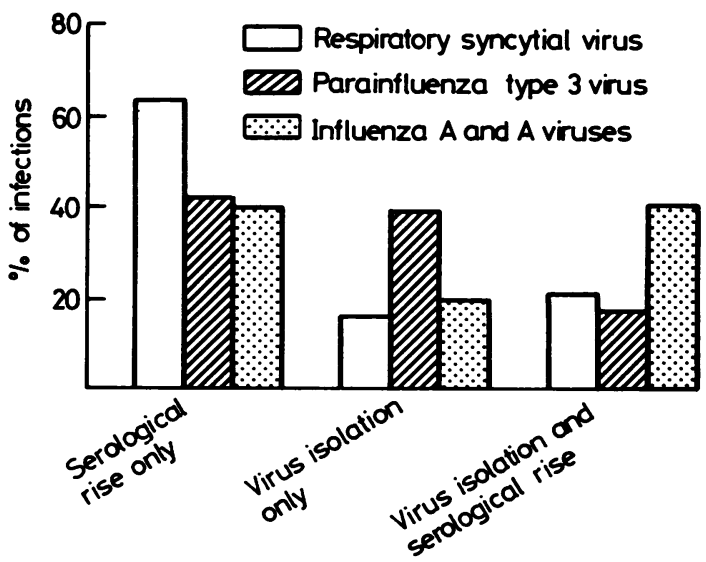

Evidence of respiratory syncytial, parainfluenza type 3, and influenza $A$ and $B$ virus infection in study infants, Houston Family Study 1975-80. Serological rise included failure of fall of passively acquired maternal antibody. 
Table 1 Virus infection rates per 100 child years for 131 infants according to sex, race, smoking.

Number of siblings and daycare: Houston Family Study, 1976-80.

\begin{tabular}{|c|c|c|c|c|c|c|c|c|c|c|c|c|c|c|}
\hline \multirow[b]{2}{*}{ Virus } & \multicolumn{2}{|c|}{$\operatorname{Sex}$} & \multicolumn{2}{|c|}{ Race } & \multicolumn{3}{|c|}{ Socioeconomic class } & \multicolumn{2}{|c|}{ Parental smoking } & \multicolumn{3}{|c|}{ No of siblings } & \multicolumn{2}{|c|}{ Daycare } \\
\hline & $\begin{array}{l}\text { Male } \\
(n=47)\end{array}$ & $\begin{array}{l}\text { Female } \\
(n=45)\end{array}$ & $\begin{array}{l}\text { White } \\
(n=59)\end{array}$ & $\begin{array}{l}\text { Non-white } \\
(n=33)\end{array}$ & $\begin{array}{l}\text { Low } \\
(n=23)\end{array}$ & $\begin{array}{l}\text { Medium } \\
(n=21)\end{array}$ & $\begin{array}{l}\text { High } \\
(n=48)\end{array}$ & $\begin{array}{l}Y e s \\
(n=37)\end{array}$ & $\begin{array}{l}\text { No } \\
(n=55)\end{array}$ & $\begin{array}{l}0 \\
(n=37)\end{array}$ & $\begin{array}{l}1 \\
(n=29)\end{array}$ & $\begin{array}{l}>2 \\
(n=26)\end{array}$ & $\begin{array}{l}Y e s \\
(n=23)\end{array}$ & $\begin{array}{l}\text { No } \\
(n=69)\end{array}$ \\
\hline Respiratory syncytial virus & 64 & 84 & 73 & 76 & 74 & 76 & 73 & 78 & 71 & 73 & 79 & 69 & 78 & 72 \\
\hline Parainfluenza type 3 & 70 & 58 & 57 & 70 & 87 & 57 & 56 & 70 & 60 & 62 & 65 & 65 & 61 & 65 \\
\hline Influenza $A$ and $B$ & 26 & 24 & 17 & $39^{*}$ & 35 & 19 & 23 & 22 & 27 & 11 & 34 & 31 & 22 & 26 \\
\hline Parainfluenza types 1 and 2 & 10 & 13 & 12 & 12 & 9 & 14 & 12 & 13 & 11 & 3 & $21 \dagger$ & 15 & 17 & 10 \\
\hline Adenoviruses & 28 & 24 & 32 & 30 & 26 & 33 & 33 & 32 & 31 & 14 & $52 \ddagger$ & 35 & 528 & 25 \\
\hline Picornaviruses unclassified & 26 & 29 & 25 & 21 & 21 & 24 & 25 & 24 & 23 & 24 & 27 & 15 & 13 & 24 \\
\hline Rhinoviruses & 44 & $84 \|$ & 61 & 70 & 56 & 67 & 66 & 49 & 74 & 48 & 76 & 72 & 1139 & 48 \\
\hline Enteroviruses & 62 & 58 & 59 & 61 & 96 & 42 & 50 & 46 & 69 & 57 & 59 & 65 & 48 & 64 \\
\hline Total virus infection & 340 & 374 & 356 & 379 & 404 & 332 & 338 & 334 & 366 & 292 & 413 & 367 & 404 & 334 \\
\hline
\end{tabular}

$x^{2}=4 \cdot 38, \mathrm{p}=0.034$.

$+0 v 1, x^{2}=5.55, p=0.018$

$\ddagger \chi^{2}=8.17, \mathrm{p}=0.017,0 \vee 1, \mathrm{p}=0.005,0 \vee<2, \mathrm{p}=0.045$.

$x^{2}=5.05, \mathrm{p}=0.023$.

$x^{2}=14.05, p=0.003$

I $x^{2}=14.86, p=0.002$.

Table 2 Respiratory illness rates per 100 child years for 131 infants according to sex, race, smoking, number of siblings, and daycare: Houston Family Study 1976-80.

\begin{tabular}{|c|c|c|c|c|c|c|c|c|c|c|c|c|c|c|}
\hline \multirow[b]{2}{*}{ Illness } & \multicolumn{2}{|c|}{ Sex } & \multicolumn{2}{|c|}{ Race } & \multicolumn{3}{|c|}{ Socioeconomic class } & \multicolumn{2}{|c|}{ Parental smoking } & \multicolumn{3}{|c|}{ No of siblings } & \multicolumn{2}{|c|}{ Daycare } \\
\hline & $\begin{array}{l}\text { Male } \\
(n=47)\end{array}$ & $\begin{array}{l}\text { Female } \\
(n=45)\end{array}$ & $\begin{array}{l}\text { White } \\
(n=59)\end{array}$ & $\begin{array}{l}\text { Non-white } \\
(n=33)\end{array}$ & $\begin{array}{l}\text { Low } \\
(n=23)\end{array}$ & $\begin{array}{l}\text { Med } \\
(n=21)\end{array}$ & $\begin{array}{l}\text { High } \\
(n=48)\end{array}$ & $\begin{array}{l}\text { Yes } \\
(n=37)\end{array}$ & $\begin{array}{l}\text { No } \\
(n=55)\end{array}$ & $\begin{array}{l}0 \\
(n=37)\end{array}$ & $\begin{array}{l}1 \\
(n=29)\end{array}$ & $\begin{array}{l}<2 \\
(n=26)\end{array}$ & $\begin{array}{l}\text { Yes } \\
(n=23)\end{array}$ & $\begin{array}{l}\text { No } \\
(n=69)\end{array}$ \\
\hline Afebrile URI & 540 & 580 & 544 & 588 & 600 & 528 & 554 & 565 & 556 & 451 & 613 & 619 & 626 & 537 \\
\hline Febrile URI & 166 & 160 & 149 & 188 & 165 & 190 & 150 & 157 & 167 & 135 & 213 & 146 & 222 & 143 \\
\hline Otitis media & 78 & 46 & 68 & 54 & 82 & 52 & 58 & 65 & 62 & 69 & 54 & 57 & 74 & 59 \\
\hline Total URI & 785 & 787 & 761 & 830 & 847 & 770 & 762 & 787 & 785 & 655 & 880 & 822 & 922 & 739 \\
\hline LTB & 62 & 42 & 58 & 42 & $78^{*}$ & 71 & 31 & 35 & 63 & 43 & 45 & 69 & 48 & 53 \\
\hline Bronchiolitis & 45 & 33 & 39 & 39 & 56 & 20 & 39 & 40 & 38 & 23 & 48 & 50 & 61 & 32 \\
\hline Pneumonia & 2 & 9 & 3 & 9 & 8 & 9 & 2 & 9 & 4 & 5 & 6 & 4 & 13 & 3 \\
\hline Total LRD & 109 & 85 & 100 & 90 & $143 \dagger$ & 100 & 72 & 84 & 105 & 71 & 99 & 123 & $122 \ddagger$ & 88 \\
\hline Total respiratory illness & 893 & 870 & 861 & 920 & 990 & 870 & 834 & 871 & 891 & 726 & 979 & 945 & 1044 & 827 \\
\hline
\end{tabular}

$* x^{2}=11.30 \mathrm{p}=0.023$ low $v$ high $\mathrm{p}=0.006 \mathrm{med} v$ high $\mathrm{p}=0.062$.

tLow $v$ high $x^{2}=8.74 p=0.032$.

$\ddagger \chi^{2}=10.67 p=0.014$.

URI $=$ Upper respiratory illnesses.

LTB = Laryngotracheobronchitis.

LRD $=$ Lower respiratory disease.

Table 1 shows that influenza $A$ and $B$ infection rates varied significantly with race. Data for 1975-6 influenza $A$ and $B$ infections were combined with the 1976-80 data because surveillance of the influenza A/Victoria epidemic that occurred was comparable with later years (table 3 ). The significant association with race was also seen in 1975-80. In addition, significant associations were found for race and influenza $A$ only $(p=0 \cdot 008)$. Seventy three per cent of these black infants had one or more siblings (1975-80) compared with $56 \%$ of white but for $1976-80$ this was reversed (black $41 \%$ white $53 \%$ ). 
Table 3 Influenza $A$ and $B$ infection rate per 100 child years according to selected social and family factors, 1975-80

\begin{tabular}{|c|c|c|}
\hline & No & $\begin{array}{l}\text { Influenza } A \& B \\
\text { infection rate }\end{array}$ \\
\hline $\begin{array}{ll}\text { Sex } & \text { Boy } \\
& \text { Girl }\end{array}$ & $\begin{array}{l}67 \\
64\end{array}$ & $\begin{array}{l}27 \\
34\end{array}$ \\
\hline $\begin{array}{r}\text { Race White } \\
\text { Other }\end{array}$ & $\begin{array}{l}72 \\
59\end{array}$ & $\begin{array}{l}19 \\
44^{*}\end{array}$ \\
\hline $\begin{array}{l}\text { Socioeconom } \\
\text { Low } \\
\text { Medium } \\
\text { High }\end{array}$ & $\begin{array}{l}61 \\
22 \\
48\end{array}$ & $\begin{array}{l}41 \\
18 \\
23\end{array}$ \\
\hline $\begin{array}{l}\text { Parental smo } \\
\text { Yes } \\
\text { No }\end{array}$ & $\begin{array}{l}66 \\
65\end{array}$ & $\begin{array}{l}33 \\
27\end{array}$ \\
\hline $\begin{array}{l}\text { No of sibling } \\
0 \\
1 \\
>2\end{array}$ & $\begin{array}{l}49 \\
41 \\
41\end{array}$ & $\begin{array}{l}18 \\
32 \\
44 \dagger\end{array}$ \\
\hline $\begin{array}{c}\text { Daycare: } \\
\text { Yes } \\
\text { No }\end{array}$ & $\begin{array}{r}30 \\
101\end{array}$ & $\begin{array}{l}33 \\
30\end{array}$ \\
\hline
\end{tabular}

$x^{2}=8.14, p=0.004$, influenza $A$ only, $p=0.036$ black $v$ white, $p=0.008$. $+\chi^{2}=6.97, p=0.030$, influenza A only, $p=0.0130 v \geqslant 2 p=0.008$.

Influenza $A$ and $B$ infection was also significantly related to number of siblings as was influenza $A$ alone $(p=0 \cdot 013)$. A stronger association was seen when comparing none with two or more siblings $(p=0.008)$. These relationships with number of siblings were not seen with the 1976-80 data only.

Independence between race and number of siblings for low socioeconomic infants was suggested by analysing all three factors simultaneously. There was a trend towards increase in the rate of infection with number of siblings for both white and non-white in the low socioeconomic group; non-white infants had higher rates compared with white in each sibling category. This was not seen in any other socioeconomic group or for the data as whole. Most influenza A and B infections (25/40), however, occurred in the low socioeconomic infants (mostly due to the A/Victoria epidemic of 1975-6) and numbers were too small in other comparisons. Regardless of how the data were grouped, all analyses comparing infants with no siblings with i infants with one or two or more siblings showed lower rates of infection in those without siblings. In addition to the association with number of siblings, $70 \%$ of infants with two or more siblings had at least one school aged sibling, whereas for those with only one, the sibling tended to be of preschool age $(15 \%$ school aged). During the epidemic of $1975-6,38 \%$ of the study infants had evidence of infection and $80 \%$ of these had school age siblings.

\section{RES PIRATORY ILLNESS}

Respiratory illness rates are shown in table 2 according to the selected social and family factors. In general, the significant relationships and interesting trends found were in the area of more severe illness. As shown in the first two columns of table 2, boys had higher rates of illness in several of the diagnostic categories but none of these trends was significant. The rate of total LRD varied significantly with both socioeconomic class (low $v$ high only) and daycare attendance, and a similar trend was noted with increasing number of siblings. There were indications that all three factors may affect total LRD independently. The larger families were distributed almost equally among all three socioeconomic classes, although low and medium classes had higher percentages of families with two or more siblings (low $39 \%$, medium $38 \%$, high $19 \%$ ). Rates of total LRD for infants with two or more siblings were found to be highest in low socioeconomic families (166 per 100 child years) and lowest in high socioeconomic class families ( 80 per 100 child years). Also the low socioeconomic families were the least likely to send their infants to daycare. Only $13 \%$ of low socioeconomic infants were in daycare compared with $28 \%$ of the medium and $35 \%$ of the high socioeconomic class infants.

Rates of total LRD for girls and boys not attending daycare were 69 and 105, respectively, while girl and boy infants attending daycare had rates of 123 and 120. Rates of bronchiolitis and pneumonia were essentially equal for both sexes in daycare.

A statistically significant variation in the rate of LTB (a component of LRD) was also found in all three socioeconomic classes, but separate analysis of medium $v$ high was found not to be significant $(p=0.062)$.

No statistically significant relationship was seen between total respiratory illness and parental smoking for the 1976-80 infants. Nevertheless, data on severe illnesses in 1975-6 were comparable with later years, and all six episodes of pneumonia that year occurred in infants of mothers who smoked. Overall, from 1975 to 1980 there were 11 episodes of pneumonia and nine (82\%) occurred in black infants of mothers who smoked. The highest rate of pneumonia (25) was found in infants with nonemployed mothers who smoked and this compared with a rate of 1.5 in those with non-employed mothers who were non-smokers $(p=0 \cdot 001)$. 


\section{Discussion}

In this study we closely monitored infants for viral infections and respiratory symptoms through the first year of life for five consecutive years. Since we studied proved viral infection regardless of illness and all illnesses regardless of severity, differences in groups based on family recognition of illness and patterns of medical care were minimised. It might therefore be expected that for such a ubiquitous group of viruses and such common illnesses the impact of family and social factors would not be impressive. In fact, we were unable to find any consistent overall relationship between respiratory viral infection or illness and the social factors studied. We had previously noted a similar lack of overall effect of breast feeding on viral respiratory infection and illness in this same population. ${ }^{10}$ Within this general similarity of experience among infants living under different conditions, however, there were selected findings of interest, especially in relation to previous reports. This group of observations will be summarised and then discussed individually. RSV and para 3 notably could not be confidently related to any of the study factors. The infection rates of rhino, influenza, and adenoviruses were all significantly associated with two of the study factors but the strongest and clearest relationships were found for influenza viruses. Respiratory illness varied significantly with the study factors only when looking at more serious illness categories. Important trends included variation in severe illness rates with sex and number of siblings while significant relationships existed between LRD, socioeconomic class, and daycare. No differences in LRD were found in relation to parental smoking as an isolated factor.

$R S \bar{V}$ is a major cause of respiratory illness in young children, especially bronchiolitis and pneumonia. ${ }^{15} 16$ Previous studies have found no correlation between RSV infection and sex, race, or socioeconomic class $^{17-19}$ although sex, low socioeconomic class, and number of siblings, may influence the outcome of infection..$^{182021}$ Our data also show no correlation between RSV infection and sex, race, or socioeconomic class, and, in addition, we found no association with daycare. The relationship to parental smoking must be considered questionable because of the limitations of the data relative to this virus in 1975-6. Hall et al also found a questionable relationship between parental smoking and RSV infection so that any association continues to be undocumented. ${ }^{22}$ Sixty nine per cent of our study infants had had at least one RSV infection; this shows the high incidence in this age group.

Parainfluenza type 3 virus is also a major cause of LTB in young children and is an important cause of bronchiolitis and pneumonia in infants and children, ${ }^{18}$ but the influence of social and family factors have been little studied. Our results show a higher incidence of initial infections among infants of low socioeconomic class but no significant association with any of the factors studied. Fifty five per cent of the infants had had at least one parainfluenza 3 virus infection.

Our study indicates that for influenza viruses (particularly type A) both race and number of siblings influence the rate of infection. Kim et al found that a larger percentage of black infants (especially boys) in hospital for respiratory illness during 11 influenza epidemics had influenza $A$ virus infection ${ }^{23}$ and our very different approach also gave indications that blacks are at a greater risk for influenza $A$ infection. The effect of race on influenza infection was not influenced by family size or socioeconomic class even though a larger number of non-whites were in the low socioeconomic class. The present data also point to older siblings, particularly school age children, as introducers; infants were more likely to be infected if they had school ages siblings in the home. This was especially true during $\vec{N}$

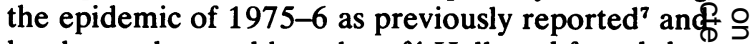
has been observed by others. ${ }^{24}$ Hall $e t$ al found tha ${ }^{2}-$ preschoolers were more often responsible for spreac 3 of infection within the family based on age-specifig infection rates, but they noted that infection rates based on a fourfold serological rise rather than the $\overrightarrow{0}$ twofold rise they used would have shifted the highes age-specific infection rates to school age children. ${ }^{25}$

Rhinovirus infection rates were found to be influenced by sex and daycare attendance. In both instances the reason appeared to be a high rate of infection in girls attending daycare for which we have no explanation.

Variation in illness with social and family factors was generally restricted to LRD rates and most of the findings reported previously also refer to LRD. Boys have been shown to have higher rates of LRD compared with girls ${ }^{581819}$ at least to the age of 6 . Although we found that the difference between boys and girls was not significant for LRD, the ratio of illness, especially when looking only at non-daycare attenders, was very close to the $60: 40$ ratio found by Gardner. ${ }^{6}$ The presence of siblings has also been shown by previous studies to affect the seriousness and number of illnesses. ${ }^{518}$ We were unable to show that the difference in illness rates between number of siblings was significant for LRD but the trend was very suggestive.

Low socioeconomic status has been thought to influence the rate of respiratory illness by means of overcrowding, large family size, and inadequate medical care. ${ }^{48}$ We provided uniform medical care 
and still found a higher rate of LRD among infants of low socioeconomic class even when controlled for family size (although numbers were small) and despite the fact that few of these infants were in daycare. Factors other than medical care or family size seem to be important influences on the incidence of LRD in the low socioeconomic infants. Trends to more infection and illness in general were present in this group.

Past studies have implicated daycare attendance as a cause of increased respiratory illness in children, especially infants. Strangert and Loda et al noted this in infants aged 6-15 months and under 12 months old, respectively. ${ }^{27}{ }^{28}$ Vihma found annual illness rates in daycare compared with home to be $6.3 v$ $2 \cdot 5 .^{29}$ These results are in agreement with our findings. In addition, we found that girl infants in daycare seem to lose the relative "protection" from LRD observed for girl infants at home. Rates of serious lower respiratory disease-that is, bronchiolitis and pneumonia-wer equal in boy and girl daycare attenders.

Infants of parents who smoked in our study were not at greater risk for viral infection or respiratory illness and even had a lower rate of LTB. The only exception to this was a significant relationship between pneumonia and parental smoking (especially mothers at home who smoked) only evident when the 1975-6 data were included. This effect could not be separated from the influence of race or socioeconomic class. Our observations are in contrast with those of Harlap and Davies ${ }^{30}$ and Leeder et al..$^{5}$ Both studies found a highly significant relationship between passive smoking and lower respiratory illness, specifically bronchitis and pneumonia. Methods in these studies differed considerably from our own; Harlap and Davies used data from large numbers of infants in hospital whereas Leeder et al followed up a cohort of children by means of yearly questionaires. Although the total number of episodes of LRD (112 including 1975) experienced by the infants in our study was small by comparison (especially pneumonia), ascertainment was more direct and illnesses were well documented.

We are grateful to Janet Wells, PAC, and her predecessors for making the Houston Family Study possible. Dr Abel Paredes participated in the study, 1975-7. Excellent management of the manuscript was provided by Kay Brown. Supported by contracts AI-92611 and AI-22672 and grant USPHS-MO1RR-0188 (Clinical Research Center) from the National Institutes of Health. Computational assistance was provided by the Clinfo project funded by the Division of Research Resources of the NIH grant number RR-00350.

\section{References}

${ }^{1}$ Monto AS, Ross $\mathrm{H}$. Acute respiratory illness in an American community, the Tecumseh study. JAMA 1974; 227: 164-9.

${ }^{2}$ Glezen WP, Loda FA, Clyde WA Jr, et al. Epidemiologic patterns of acute lower respiratory disease of children in a pediatric group practice. $J$ Pediatr 1971; 78: 397-406.

s Backstrom-Sarvinen L, Thsala R. Kantero RL, Hallman N. Illness among normal Finnish children during the first five years of life. Annales Paediatriac Fenniac 1966; 12: 13-9.

${ }^{4}$ Dingle JH, Badger CF, Jordan WS. Illness in the home. Cleveland: The Press of Western Reserve University, 1964.

${ }^{3}$ Leeder SR, Corkhill R, Irwig CM, Holland WW, Colley JRT. Influence of family factors on the incidence of lower respiratory illness during the first year of life. $\mathrm{Br} J$ Prev Soc Med 1976; 30: 203-12.

${ }^{6}$ Gardner PS. Virus infections and respiratory disease of childhood. Arch Dis Child 1968; 43: 629-45.

${ }^{7}$ Taber $\mathbf{L H}$. Infection with influenza $\mathrm{A} /$ Victoria virus in Houston families, 1976. J Hyg 1981; 86: 30313.

'Frank AL, Taber LH, Wells JM. Individuals infected with two subtypes of influenza $A$ virus in the same season. J Infect Dis 1983; 147: 120-4.

${ }^{\circ}$ Frank AL, Taber LH, Glezen WP, Kasel GL, Wells CR, Paredes A. Breast-feeding and respiratory virus infection. Pediatrics 1982: 70: 239-45.

${ }^{10}$ Baxter BD, Couch RB, Greenberg SB, et al. Maintenance of viability and comparison of identification methods for influenza and respiratory viruses of humans. J Clin Microbiol 1977; 6: 19-22.

${ }^{11}$ Frank AL, Couch RB, Griffis CA, et al. Comparison of different tissue cultures for isolation and quantitation of influenza and parainfluenza viruses. J Clin Microbiol 1979; 10: 32-6.

${ }^{12}$ Dowdle WA, Kendal AP, Noble G. Influenza viruses. In: Lennette $\mathrm{EH}$, and Schmidt NJ, eds. Diagnostic procedures for viral, rickettsial and chlamydial infections. Washington, DC: American Public Health Association, 1979: 585-609.

${ }^{13}$ Glezen WP, Paredes A, Allison JE, et al. Risk of respiratory syncytial virus infection for infants from low income families in relationship to age, sex, ethnic group and maternal antibody level. $J$ Pediatr 1981; 98: 708-15.

${ }^{14}$ Frank AL, Puck J, Hughes BJ, Cate TR. Microneutralization test for influenza $A$ and $B$ and parainfluenza 1 and 2 viruses that uses continuous cell lines and fresh serum enhancement. $J$ Clin Microbiol 1980; 12: 426-32.

${ }^{15}$ Chanock RM, Parrot RH. Acute respiratory disease in infancy and childhood: present understanding and prospects for prevention. Pediatrics 1965; 36: 21-39.

${ }^{16}$ Murphy TF, Henderson FW, Clyde WA Jr, Collier AM. Denney FW. Pneumonia: an eleven-year study in a pediatric practice. Am J Epidemiol 1981; 113: 12-21.

${ }^{17}$ Parrot RH, Kim HW, Arrobio DS, et al. Epidemiology of respiratory syncytial virus infection in Washington, DC. II. Infection and disease with respect to age immunologic status, race and sex. Am J Epidemiol 1973; 98: 289-300. 
${ }^{18}$ Glezen WP, Denny FW. Epidemiology of acute lower respiratory disease in children. $N$ Engl $J$ Med 1973; 288: 498-504.

${ }^{10}$ Orstavik I, Carlsen KH, Halvorsen K. Respiratory syncytial virus infections in Oslo 1972-1978. I. Virological and epidemiologic studies. Acta Paediatr Scand 1978; 69: 717-22.

${ }^{20}$ Clarke SKR, Gardner PS, Poole PM, Simpson H, Tobin JO. Respiratory syncytial virus infection. Admissions to hospitals in industrial, urban, and rural areas. $\mathrm{Br} \mathrm{Med} J \mathrm{1978}$; ii: 796-8.

${ }^{21}$ Sims OG, Downham MAPS, McQuillin J, Gardner PS. Respiratory syncytial virus infection in northeast England. Br Med J 1976; ii: 1095-8.

${ }^{22}$ Hall CB, Geiman JM, Biggar RB, Rotok DJ, Hogan DM, Douglas RG. Respiratory syncytial virus infections within families. N Engl J Med 1976; 294: 414-9.

${ }^{28} \mathrm{Kim}$ HW, Brandt CD, Arrosio JO, Murphy B, Chanock RM, Parrot RH. Influenza $A$ and $B$ virus infection in infants and young children during the years 1957-76. Am J Epidemiol 1979; 109: 46479.
${ }^{24}$ Jordan WS Jr. The mechanism of spread of Asian influenza. Am Rev Respir Dis 1961; 83: 29-38.

${ }^{25}$ Hall CE, Cooney MK, Fox JP. The Seattle virus watch. IV. Comparative epidemiologic observations of infections with influenza A and B viruses 1965-1969 in families with young children. Am J Epidemiol 1973; 98: 365-80.

${ }^{26}$ Colley JRT. The vulnerable child. $J R$ Coll Gen Pract 1975; 25: 257-62.

${ }^{27}$ Strangert K. Respiratory illness in preschool children with different forms of daycare. Pediatrics 1976; 57: 191-6.

${ }^{28}$ Loda FA, Glezen WP, Clyde WA Jr. Respiratory disease in group day care. Padiatrics 1972; 49: 428-37.

${ }^{29}$ Vihma L. Surveillance of acute viral respiratory disease in children. Acta Paediatr Scand 1969; 192, suppl: 1-52.

${ }^{30}$ Harlap S, Davies AM. Infant admissions to hospital and maternal smoking. Lancet 1974; i: 529-32. 